\title{
Soil, plant, and transport influences on methane in a subalpine forest under high ultraviolet irradiance
}

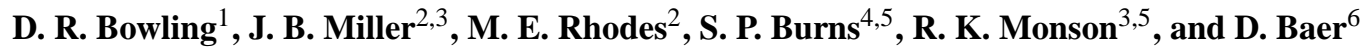 \\ ${ }^{1}$ Department of Biology, 257 South 1400 East, University of Utah, Salt Lake City, UT, 84112-0840, USA \\ ${ }^{2}$ National Oceanic and Atmospheric Administration, Earth System Research Laboratory, Boulder, CO, 80305, USA \\ ${ }^{3}$ Cooperative Institute for Research in Environmental Science, University of Colorado, Boulder, CO, 80309, USA \\ ${ }^{4}$ National Center for Atmospheric Research, Boulder, CO, 80305, USA \\ ${ }^{5}$ Department of Ecology and Evolutionary Biology, University of Colorado, Boulder, CO, 80309, USA \\ ${ }^{6}$ Los Gatos Research, Mountain View, CA, 94041, USA
}

Received: 7 April 2009 - Published in Biogeosciences Discuss.: 5 May 2009

Revised: 7 July 2009 - Accepted: 23 July 2009 - Published: 30 July 2009

\begin{abstract}
Recent studies have demonstrated direct methane emission from plant foliage under aerobic conditions, particularly under high ultraviolet (UV) irradiance. We examined the potential importance of this phenomenon in a high-elevation conifer forest using micrometeorological techniques. Vertical profiles of methane and carbon dioxide in forest air were monitored every $2 \mathrm{~h}$ for 6 weeks in summer 2007. Day to day variability in above-canopy $\mathrm{CH}_{4}$ was high, with observed values in the range 1790 to $1910 \mathrm{nmol} \mathrm{mol}^{-1}$. High $\mathrm{CH}_{4}$ was correlated with high carbon monoxide and related to wind direction, consistent with pollutant transport from an urban area by a well-studied mountain-plain wind system. Soils were moderately dry during the study. Vertical gradients of $\mathrm{CH}_{4}$ were small but detectable day and night, both near the ground and within the vegetation canopy. Gradients near the ground were consistent with the forest soil being a net $\mathrm{CH}_{4}$ sink. Using scalar similarity with $\mathrm{CO}_{2}$, the magnitude of the summer soil $\mathrm{CH}_{4}$ sink was estimated at $\sim 1.7 \mathrm{mg} \mathrm{CH}_{4} \mathrm{~m}^{-2} \mathrm{~h}^{-1}$, which is similar to other temperate forest upland soils. The high-elevation forest was naturally exposed to high UV irradiance under clear sky conditions, with observed peak UVB irradiance $>2 \mathrm{~W} \mathrm{~m}^{-2}$. Gradients and means of $\mathrm{CO}_{2}$ within the canopy under daytime conditions showed net uptake of $\mathrm{CO}_{2}$ due to photosynthetic drawdown as expected. No evidence was found for a significant foliar $\mathrm{CH}_{4}$ source in the vegetation canopy, even under high UV conditions. While the possibility of a weak foliar source
\end{abstract}

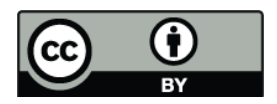

Correspondence to: D. R. Bowling (bowling@biology.utah.edu) cannot be excluded given the observed soil sink, overall this subalpine forest was a net sink for atmospheric methane during the growing season.

\section{Introduction}

Methane is a greenhouse gas that is primarily produced by metabolism of obligate anaerobic microorganisms (Cicerone and Oremland, 1988). Although there is less $\mathrm{CH}_{4}$ in the air than $\mathrm{CO}_{2}$, the radiative forcing of $\mathrm{CH}_{4}$ is significant and amounts to about one third of the forcing caused by $\mathrm{CO}_{2}$ (Forster et al., 2007). Atmospheric $\mathrm{CH}_{4}$ has been increasing during the last several hundred years due to human modification of agricultural systems and other human activities (Dlugokencky et al., 1994; Etheridge et al., 1998; Ferretti et al., 2005). During the last 15 years, the atmospheric increase rate slowed to near zero (Dlugokencky et al., 2003), but $\mathrm{CH}_{4}$ has recently begun to increase again around the world (Rigby et al., 2008). The atmospheric $\mathrm{CH}_{4}$ burden represents the net balance of extremely large sources and sinks, and while some of these are fairly well understood, others are not. The causes of the recent changes in methane increase rate remain unknown. There is a need to understand the biogeochemical processes involved in methane production and oxidation, including those in terrestrial ecosystems, if we are to make defensible estimates of the $\mathrm{CH}_{4}$ cycle in the future.

Until recently, the role of living plants in the methane cycle was thought to be limited to transport of microbiallyproduced $\mathrm{CH}_{4}$ through aerenchyma in herbaceous wetland plants and some woody plants (Schimel, 1995; Rusch and

Published by Copernicus Publications on behalf of the European Geosciences Union. 
Rennenberg, 1998; Terazawa et al., 2007). A recent paper by Keppler et al. (2006) suggested the intriguing possibility that vascular plants emit $\mathrm{CH}_{4}$ directly, under aerobic conditions, and without the involvement of microorganisms. These workers used their initial experiments to estimate the global significance of aerobic plant emission, and reported that as much as $240 \mathrm{Tg} \mathrm{CH}_{4} \mathrm{yr}^{-1}$ might be produced by living plants (and more from plant litter). This factor is as large as many estimates of global wetland sources, and larger than the combined emissions from rice agriculture and ruminants (Denman et al., 2007), although many studies since then have placed the upper limit closer to $50-100 \mathrm{Tg} \mathrm{CH}_{4} \mathrm{yr}^{-1}$ (Houweling et al., 2006; Kirschbaum et al., 2006; Ferretti et al., 2007). Not surprisingly, this finding has generated a vigorous scientific debate, focused on the possible global significance of plant methane emission (Bousquet et al., 2006; Houweling et al., 2006; Kirschbaum et al., 2006; Bergamaschi et al., 2007; Miller et al., 2007; Frankenberg et al., 2008; Houweling et al., 2008; Meirink et al., 2008), as well as the underlying mechanism of emission.

Several studies from independent laboratories have now convincingly demonstrated direct $\mathrm{CH}_{4}$ emission from plants (Keppler et al., 2006; Cao et al., 2008; Keppler et al., 2008; McLeod et al., 2008; Vigano et al., 2008; Wang et al., 2008; Bruggemann et al., 2009; Messenger et al., 2009; Wang et al., 2009), but studies by other groups have failed to find it (Dueck et al., 2007; Beerling et al., 2008; Kirschbaum and Walcroft, 2008). It appears that ultraviolet radiation is required for plant emission (McLeod et al., 2008; Vigano et al., 2008; Messenger et al., 2009), and the lack of UV in some experimental studies may help resolve these conflicting results. UV is not always required, however; very high temperature (Vigano et al., 2008) and physical damage to plant tissues (Wang et al., 2009) can also stimulate emission. Very low rates have been observed under low light without UV in poplar shoot cultures, with strong evidence that microbial organisms are not required for $\mathrm{CH}_{4}$ production (Bruggemann et al., 2009).

A consensus is emerging that the mechanism of plant emission may be biophysical rather than from direct production of $\mathrm{CH}_{4}$ via a plant metabolic pathway. Emission occurs upon UV irradiation of synthetic plant pectin and related plant structural compounds (Keppler et al., 2008; McLeod et al., 2008). This is likely via a UV-initiated free-radical chemical process (Sharpatyi, 2007). Addition of chemicals that scavenge reactive oxygen species (ROS) strongly inhibits UV-induced $\mathrm{CH}_{4}$ emission from pectin, and $\mathrm{CH}_{4}$ emission in the dark can occur when certain ROS are added to pectin (Messenger et al., 2009). Other environmental stressors can initiate formation of ROS (Apel and Hirt, 2004), so it is possible that factors other than UV might induce $\mathrm{CH}_{4}$ emission from plants (Messenger et al., 2009).

Most studies investigating $\mathrm{CH}_{4}$ emission from plants have been conducted in the laboratory, using either artificial lamps or sunshine (e.g., Keppler et al., 2006; Vigano et al., 2008).
The few studies that have directly observed plant $\mathrm{CH}_{4}$ emission in the field (Sanhueza and Donoso, 2006; Cao et al., 2008; Wang et al., 2008) have used chambers or vials with detached (or rarely intact) plant tissues, which limit or omit UV irradiation relative to a plant's natural environment. At present, we have virtually no basis to compare $\mathrm{CH}_{4}$ emission rates measured in the lab using artificial lamps to those that might be expected in the field under natural sunlight without chambers.

The soils of most upland forests act as a sink for methane (Dutaur and Verchot, 2007) due to the metabolic activity of methanotrophic microorganisms (King, 1992). In ecosystems dominated by plants that do emit $\mathrm{CH}_{4}$, the presence of a local soil sink could limit the overall importance of plant production to the atmospheric $\mathrm{CH}_{4}$ budget. However, to date there have been no studies that were specifically designed to evaluate the ecological significance of plant methane emission from whole ecosystems under natural conditions in the field.

Our primary objective was to examine the general patterns of summer methane exchange in an upland subalpine conifer forest. The forest was located at high elevation and naturally exposed to high UV irradiance, providing an ideal situation to examine plant and soil $\mathrm{CH}_{4}$ exchange processes under natural conditions. Micrometeorological techniques were used to avoid the microclimatic and radiative artifacts of plant and soil chambers. In this paper we examine the causes for variability of $\mathrm{CH}_{4}$ in subalpine forest air, including forest biological processes and atmospheric transport. We investigate local soil production and consumption of methane, and the magnitude of soil-atmosphere exchange. Measurements of $\mathrm{CO}_{2}$ and $\mathrm{CO}$ are used to provide some understanding of expected $\mathrm{CH}_{4}$ patterns within the forest and of transport of urban air masses. Finally, we address the importance of aerobic $\mathrm{CH}_{4}$ emission from foliage in the context of whole-forest biosphere-atmosphere exchange.

\section{Methods}

\subsection{Study location}

The primary study site was a subalpine conifer forest (the $\mathrm{Ni}$ wot Ridge AmeriFlux forest) in the southern Rocky Mountains of the United States $\left(40.03^{\circ} \mathrm{N}, 105.55^{\circ} \mathrm{W}, 3050 \mathrm{~m}\right.$ elevation). The roughly 110 -yr old stand is dominated by Pinus contorta (lodgepole pine), Picea engelmannii (Engelmann spruce), and Abies lasiocarpa (subalpine fir), with a sparse understory. The mean annual temperature is $1.5^{\circ} \mathrm{C}$, and the mean annual precipitation is $800 \mathrm{~mm}$, roughly $40 \%$ of which is snow in winter. Further site details and information about measurement of weather and environmental parameters, energy and $\mathrm{CO}_{2}$ exchange can be found elsewhere (Monson et al., 2002, 2006). 


\subsection{In-situ methane and carbon dioxide analysis}

Vertical profiles of $\mathrm{CH}_{4}$ and $\mathrm{CO}_{2}$ were measured in the forest during 28 June-10 August, 2007 (day of year 179-222). Measurement heights were $21.5 \mathrm{~m}$ (above the vegetation canopy), 11, 9, and $7 \mathrm{~m}$ (within the canopy, vegetation height was $11-12 \mathrm{~m}$ ), and $1,0.5$, and $0.1 \mathrm{~m}$ (in the sub-canopy air space near the ground). The inlet system (described in detail by Schaeffer et al., 2008b) was time-multiplexed with other instrumentation; $\mathrm{CH}_{4}$ and $\mathrm{CO}_{2}$ were measured during one $0.5 \mathrm{~h}$ subset of each $2 \mathrm{~h}$ period. The full profile for both gases was measured within a half hour, on the same gas samples simultaneously. Air flowed continuously through sampling lines and was sub-sampled for analysis. $\mathrm{CH}_{4}$ mole fraction was measured using off-axis integrated-cavity output spectroscopy (Model 908-0001, Fast Methane Analyzer, Los Gatos Research, Mountain View, CA). $\mathrm{CO}_{2}$ and $\mathrm{H}_{2} \mathrm{O}$ vapor mole fraction were measured using a non-dispersive infrared gas analyzer (LI-7000, Li-cor, Lincoln, NE). All $\mathrm{CH}_{4}$ and $\mathrm{CO}_{2}$ mole fractions are reported relative to World Meteorological Organization (WMO) calibration scales, which are maintained at the National Oceanic and Atmospheric Administration/Earth System Research Laboratory (NOAA/ESRL, http://www.esrl.noaa.gov/). During the $1.5 \mathrm{~h}$ not devoted to methane measurements, $\mathrm{CO}_{2}$ and $\delta^{13} \mathrm{C}$ of $\mathrm{CO}_{2}$ were measured as described by Schaeffer et al. (2008b); these data are not used in the present paper.

A 4-way crossover valve (Valco E4UWE, Houston, TX) was used to route sample air from the selected tower inlet to the selected analyzer. When a given analyzer was not in use, the crossover valve was plumbed to route filtered room air to the analyzer. Immediately downstream of the crossover valve, sample air entered a $2.4 \mathrm{~m}$ length of $1.5 \mathrm{~mm}$ inner diameter Nafion membrane (Nafion MD-070-96P-2, Toms River, $\mathrm{NJ}$ ) to remove moisture. The countercurrent flow on the outside of the Nafion membrane was generated by pumping room air through a 80/20 500 g mixture of molecular sieve $4 \mathrm{a}$ (Acros Organics, Morris Plains, NJ) and indicating dessicant (Drierite, Xenia, $\mathrm{OH}$ ). The flow was maintained at $400 \mathrm{sccm}$ (twice that of the sample flow) using a needle valve downstream of the moisture trap. The minimum dew point achieved using this method was $-26^{\circ} \mathrm{C}$ and averaged $-18^{\circ} \mathrm{C}$. The moisture traps were changed every $7-10$ days after which time the dew point averaged $-14^{\circ} \mathrm{C}$; in one case the dew point rose as high as $5^{\circ} \mathrm{C}$ for one $24 \mathrm{~h}$ period. After drying, the air passed into the $\mathrm{CH}_{4}$ analyzer via a 2 micron high flow filter (Nupro SS-44FW4-2, Solon, OH). The flow rate through the analyzer was maintained at $200 \mathrm{sccm}$ using the analyzer's internal pump and a mass flow controller immediately downstream of the instrument. The flow was tuned to optimize both the drying and cell flushing. The exhaust flow of the $\mathrm{CH}_{4}$ analyzer was routed to the sample cell of the LI-7000 for $\mathrm{CO}_{2}$ and $\mathrm{H}_{2} \mathrm{O}$ measurement, while dry $\mathrm{N}_{2}$ flowed through the reference cell at $10 \mathrm{sccm}$.
The $\mathrm{CH}_{4}$ analyzer was calibrated using whole air from high pressure cylinders that were calibrated for $\mathrm{CH}_{4}$ at NOAA/ESRL prior to deployment. A two-point calibration was employed (zero, and span, $1713.9 \pm 0.8 \mathrm{nmol} \mathrm{mol}^{-1}$ ) given the stability of the analyzer. Additionally, a second calibrated $\mathrm{CH}_{4}$ tank $\left(1909.2 \pm 0.8 \mathrm{nmol} \mathrm{mol}^{-1}\right)$ was used as a "target tank" to independently gauge the "measurement trueness" (accuracy) and "measurement reproducibility" (precision) (JCGM, 2008). The reproducibility as indicated by replicate measurements of the target tank was $0.35 \mathrm{nmol} \mathrm{mol}^{-1}$. The difference between measured and calibrated value of the target tank was $+2.8 \mathrm{nmol} \mathrm{mol}^{-1}$ (1912.0-1909.2), which is within $0.15 \%$ of the calibrated target tank (note the reference gas used for calibration was $1713.9 \mathrm{nmol} \mathrm{mol}^{-1}$ ). When the target tank was measured following calibration with a tank closer to the reference gas $\left(1842.5 \mathrm{nmol} \mathrm{mol}^{-1}\right)$, the difference was only $1.0 \mathrm{nmol} \mathrm{mol}^{-1}$. This "gain" difference amounts to only 0.01 , indicating that, for example, a measured vertical or temporal difference of $20 \mathrm{nmol} \mathrm{mol}^{-1}$ would be in error by only about $0.2 \mathrm{nmol} \mathrm{mol}^{-1}$. Like methane, in addition to the seven levels, for $\mathrm{CO}_{2}$ both a reference and target gas were introduced into the sample cell, in order to calibrate the measurements to the WMO scale and verify the calibration. Although the target gas exhibited a linear $\mathrm{CO}_{2}$ drift of about $0.03 \mu \mathrm{mol} \mathrm{mol}^{-1} \mathrm{day}^{-1}$, the residual standard deviation from that drift was $0.2 \mu \mathrm{mol} \mathrm{mol}^{-1}$; the mean offset from the assigned value was $-2.1 \mu \mathrm{mol} \mathrm{mol}^{-1}$ at a distance from the reference gas of $152 \mu \mathrm{mol} \mathrm{mol}^{-1}$. For both $\mathrm{CH}_{4}$ and $\mathrm{CO}_{2}$, the precision and stability of our analysis system indicates our ability to resolve small atmospheric gradients.

Average $\mathrm{CH}_{4}$ mole fractions for a given intake height at a given time were determined as the mean of the last $60 \mathrm{~s}$ of $200 \mathrm{~s}$ dwell time at a given level or gas cylinder; the majority of this time was used to flush the sample cell of the analyzers completely, based on pre-deployment bench tests. For the target tank, the reproducibility was calculated as the one sigma standard deviation of these means over the entire measurement period (day of year 179-222).

Drying air and/or calculating its moisture content was necessary to determine accurate methane mole fractions. In particular, the WMO methane scale is defined as "dry air mole fraction": $\mathrm{nmol} \mathrm{CH}_{4}$ (mol dry air) ${ }^{-1}$. Thus a dilution correction must be made to the raw output of a spectrometer that measures the ratio of $\mathrm{CH}_{4}$ to total pressure, which includes the $\mathrm{H}_{2} \mathrm{O}$ vapor partial pressure. For example, a raw measurement of $1800 \mathrm{nmol} \mathrm{CH}_{4} \mathrm{~mol}^{-1}$ with a water content of $1000 \mathrm{mmol} \mathrm{H}_{2} \mathrm{O} \mathrm{mol} \mathrm{air}{ }^{-1}-\mathrm{a}$ dew point of about $-26^{\circ} \mathrm{C}$ at the pressure and typical temperature of the site - is $1801.8 \mathrm{nmol} \mathrm{CH}_{4} \mathrm{~mol}^{-1}$ after correction. For a dew point of $4^{\circ} \mathrm{C}\left(\sim 12500 \mathrm{mmol} \mathrm{H}_{2} \mathrm{O}\right.$ mol air $\left.{ }^{-1} \mathrm{H}_{2} \mathrm{O}\right)$, typical of daytime ambient conditions, the correction would be about $20 \mathrm{nmol} \mathrm{CH}_{4} \mathrm{~mol}^{-1}$. Our primary strategy was to dry the air, and we additionally measured its moisture content with the LI-7000 to be able to correct it regardless of the efficiency 
of drying. Moreover, even when undried and uncorrected, small gradients of water vapor do not contribute significant artifacts to observed $\mathrm{CH}_{4}$ gradients; the largest $\mathrm{H}_{2} \mathrm{O}$ vapor gradient we observed was less than $200 \mathrm{mmol} \mathrm{H}_{2} \mathrm{O} \mathrm{mol} \mathrm{air}{ }^{-1}$ after the dessicant ran out.

\subsection{Automated flask collection for methane and carbon monoxide analysis}

Air samples from the primary study site, and a second alpine tundra site, were collected in glass flasks for laboratory analysis of several trace gases, including $\mathrm{CH}_{4}$ and $\mathrm{CO}$. These data were used to provide an indicator of regional transport of urban air. The tundra site $\left(40.05^{\circ} \mathrm{N}, 105.58^{\circ} \mathrm{W}, 3423 \mathrm{~m}\right.$, NOAA/ESRL site NWR) was located approximately $3 \mathrm{~km}$ to the NW and $373 \mathrm{~m}$ higher in elevation from the forest site. Samples were collected using an automated flask sampler described by Schaeffer et al. (2008b), with simultaneous collection at both sites, at midday $(14: 00 \mathrm{~h})$ and at night $(02: 00 \mathrm{~h})$, every other day. $\mathrm{CH}_{4}$ and $\mathrm{CO}$ mole fractions were measured in the flasks by the NOAA Carbon Cycle Greenhouse Gases Group as described by Schnell (2004). To investigate general patterns of arrival of polluted urban air at the sites, flask data are presented from the period 18 September 2005 to 12 October 2007 (all data available), and for the subset of time during summer 2007 (days 170-230) in this paper.

\subsection{Ultraviolet irradiance}

Ambient UV irradiance data were obtained from the NOAA-EPA Brewer Spectrophotometer UV Network (http:// www.esrl.noaa.gov/gmd/grad/neubrew/) for an adjacent site (MRS, CO), located $1.1 \mathrm{~km}$ east of the forest site and $127 \mathrm{~m}$ lower in elevation. These data include radiant spectral flux density in the 286.5 to $363 \mathrm{~nm}$ range, with one full spectrum collected roughly every $15 \mathrm{~min}$ during daylight hours. Spectral UV data were integrated to calculate total irradiance in a particular wavelength range, and then averaged on a 30-min basis to match trace gas analysis periods. The measurement range of the instrumentation was narrower than the usual definition of UVA (315-400 nm) and UVB (280-315 nm) wavelength ranges (McKenzie et al., 2004). This leads to an underestimation in our reported UVA irradiance by roughly a factor of 2 (under clear sky conditions) relative to the irradiance in the unweighted full UVA range (see Fig. 1). There is little UVB at Niwot Ridge in the unmeasured higher-energy region of 280 to $286.5 \mathrm{~nm}$, so our reported irradiance is indicative of the true UVB irradiance.

\subsection{Data selection and analysis: "gradients" and "daytime excess"}

Daytime and nighttime periods were selected based on analysis of solar radiation versus time of day. $\mathrm{CH}_{4}$ and $\mathrm{CO}_{2}$ data are presented for daytime (06:15 to 17:15 h local time) and

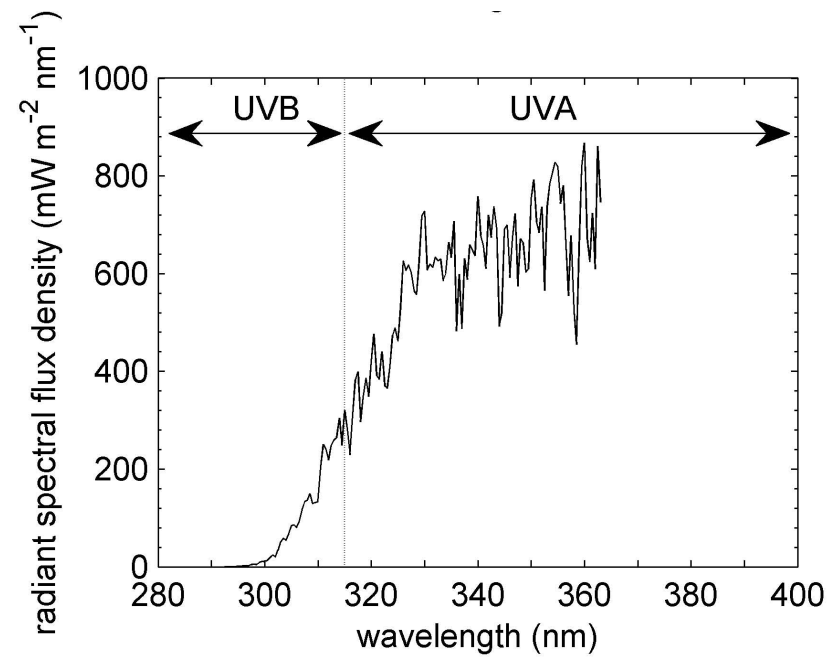

Fig. 1. A typical UV irradiance spectrum at Niwot Ridge (midday on day 203). The vertical line divides the standard UVB (left, 280$315 \mathrm{~nm}$ ) and UVA (right, $315-400 \mathrm{~nm}$ ) ranges.

nighttime (19:15 to $04: 15 \mathrm{~h}$ ) periods separately, and we ignore the 2-h transition periods between to avoid complexities of storage fluxes. In all, 238 daytime and 164 nighttime profiles were obtained. Data were analyzed separately for the within-canopy inlets $(7,9,11 \mathrm{~m})$ and the near-ground inlets $(0.1,0.5,1 \mathrm{~m})$, assuming these to be indicative of canopy and soil processes, respectively. There is strong evidence for the validity of this assumption under stable atmospheric conditions at night (Yi et al., 2005; Schaeffer et al., 2008a). During the day, processes from each vertical zone will certainly influence the other. For each group, gradients were calculated as the slope of a least-squares linear regression (mole fraction versus height) through the three grouped inlets. The daytime excess content of each trace gas within the vegetation canopy was calculated as the mean of the mole fractions at the 3 canopy inlets minus the mole fraction at $21.5 \mathrm{~m}$. Daytime excess is used as an index of canopy physiological activity. Note that the daytime excess is in effect a gradient (from within the canopy region to above it) but is expressed as a mole fraction difference. A positive daytime excess should generally indicate a source within the forest, a negative one a sink.

\section{Results and discussion}

\subsection{Environmental conditions and observed $\mathrm{CH}_{4}$ and $\mathrm{CO}_{2}$}

Environmental conditions during the study are shown in Fig. 2. Most days were sunny in the morning with some afternoon cloud cover, and later in the summer afternoon rainstorms increased soil moisture. Air temperature peaked at $24.5^{\circ} \mathrm{C}$, and although there were some cold nights, soils 


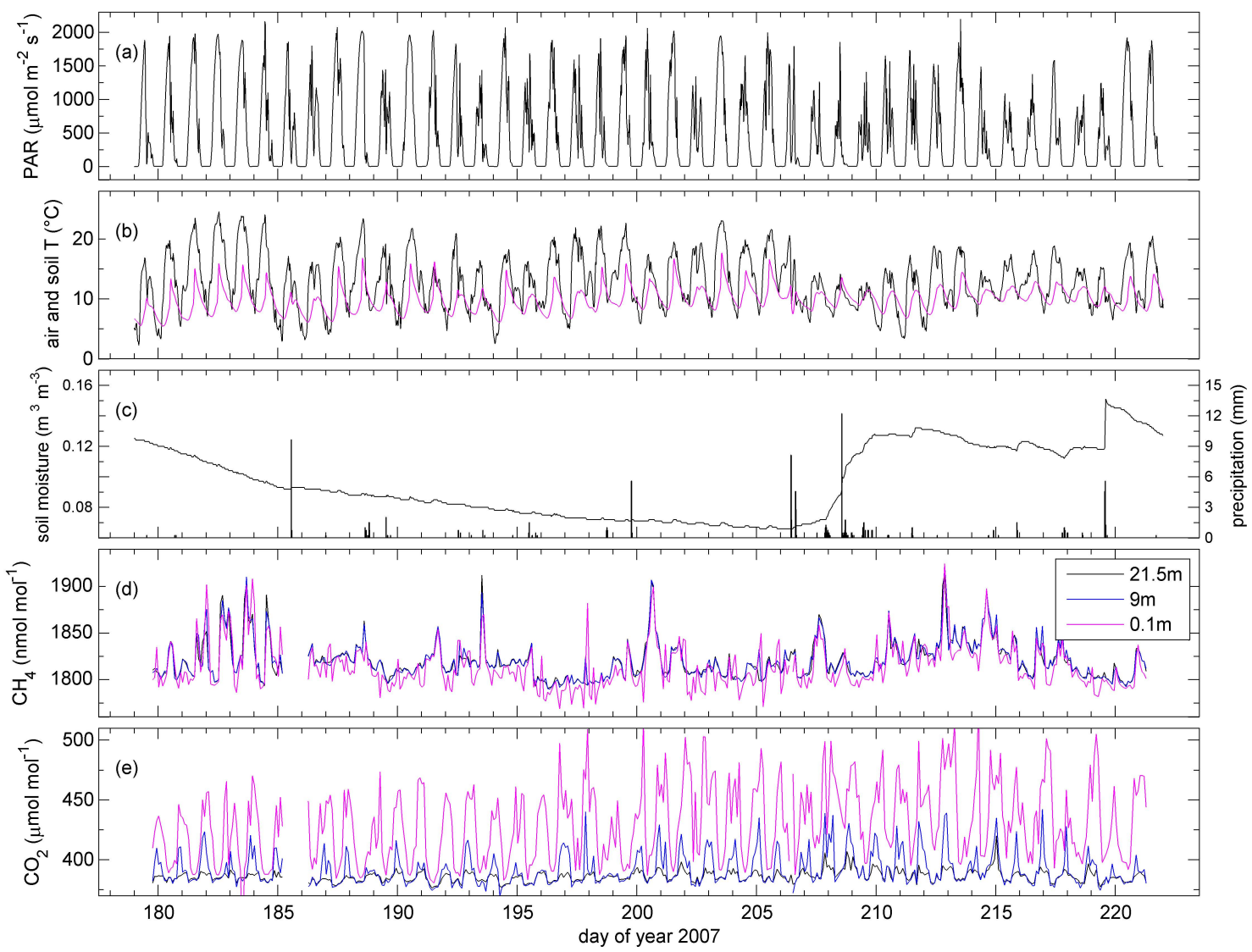

Fig. 2. Environmental conditions, methane, and carbon dioxide mole fractions during the study. (a) above-canopy photosynthetically active radiation (PAR), (b) air temperature at $8 \mathrm{~m}$ (black line), and soil temperature at $5 \mathrm{~cm}$ depth (pink line), (c) soil moisture at $5 \mathrm{~cm}$ depth (line, left axis) and above-canopy precipitation (total in a 30-min period, bars, right axis), (d) $\mathrm{CH}_{4}$ mole fractions, and (d) $\mathrm{CO}_{2}$ mole fractions at 3 measurement heights within the forest. The legend in (d) also applies to (e).

never experienced freezing conditions (soil temperature data not shown). Precipitation during June (the month preceding the study) was very low (70\% of normal for the month), and July/August precipitation were fairly normal. Near-surface soils during the study were moderately dry, with water content declining for the first 30 days from 12 to $8 \%$, and increasing following the late summer rains to about $15 \%$ (field capacity of these soils is $\sim 40 \%$ ).

Several studies have recently highlighted the importance of UV radiation for aerobic methane production by plants (Keppler et al., 2008; McLeod et al., 2008; Vigano et al., 2008; Messenger et al., 2009). The high elevation of the Niwot Ridge forest led to high solar irradiance (Fig. 3). Incident photosynthetically active radiation peaked above $2000 \mu \mathrm{mol} \mathrm{m}^{-2} \mathrm{~s}^{-1}$, with UVA (in the limited measurement range) exceeding $30 \mathrm{~W} \mathrm{~m}^{-2}$, and UVB greater than $2 \mathrm{~W} \mathrm{~m}^{-2}$. On average the daily UV fluxes peaked at 20 and $1.4 \mathrm{~W} \mathrm{~m}^{-2}$, respectively (Fig. 3). In a laboratory study with artificial lamps, Vigano et al. (2008) reported a fairly high methane emission rate $\left(55 \mathrm{ng} \mathrm{CH}_{4}(\mathrm{~g} \mathrm{dw})^{-1} \mathrm{~h}^{-1}\right)$ from living conifer foliage (Pinus ponderosa) under total UV irradiance of $38 \mathrm{~W} \mathrm{~m}^{-2}$ (note that their UVB irradiance of $24 \mathrm{~W} \mathrm{~m}^{-2}$ was a much higher portion of the total than ours). As discussed, our UVA values are probably underestimated by a factor of two, so based on the Vigano et al. study one might expect the UV at the Niwot Ridge forest to be sufficient to cause $\mathrm{CH}_{4}$ emission from Pinus species. The dominant tree species are all conifers, including $P$. contorta, which is congeneric to the pine used by Vigano et al. (2008).

Shown in Fig. $2 \mathrm{~d}$ and e are time series of $\mathrm{CH}_{4}$ and $\mathrm{CO}_{2}$ measured above-, within-, and below-canopy. $\mathrm{CO}_{2}$ exhibited a distinct diel pattern, with highest $\mathrm{CO}_{2}$ near the ground due to soil respiration. Day to day variability in $\mathrm{CH}_{4}$ was high. The amplitude of the seasonal cycle of $\mathrm{CH}_{4}$ at Niwot Ridge is roughly $50 \mathrm{nmol} \mathrm{mol}^{-1}$ (Dlugokencky et al., 1994), and change during our summer study period that is driven by the seasonal cycle at this latitude should be maximally around $5 \mathrm{nmol} \mathrm{mol}^{-1}$ (Shipham et al., 1998a). Simpson et al. (1999) reported a systematic shift in $\mathrm{CH}_{4}$ during the growing season in a boreal aspen forest, and attributed it to increased soil production (as soil temperature increased). Neither $\mathrm{CH}_{4}$ mole fraction nor soil temperature changed markedly over the course of our study (Fig. 2b and d). 

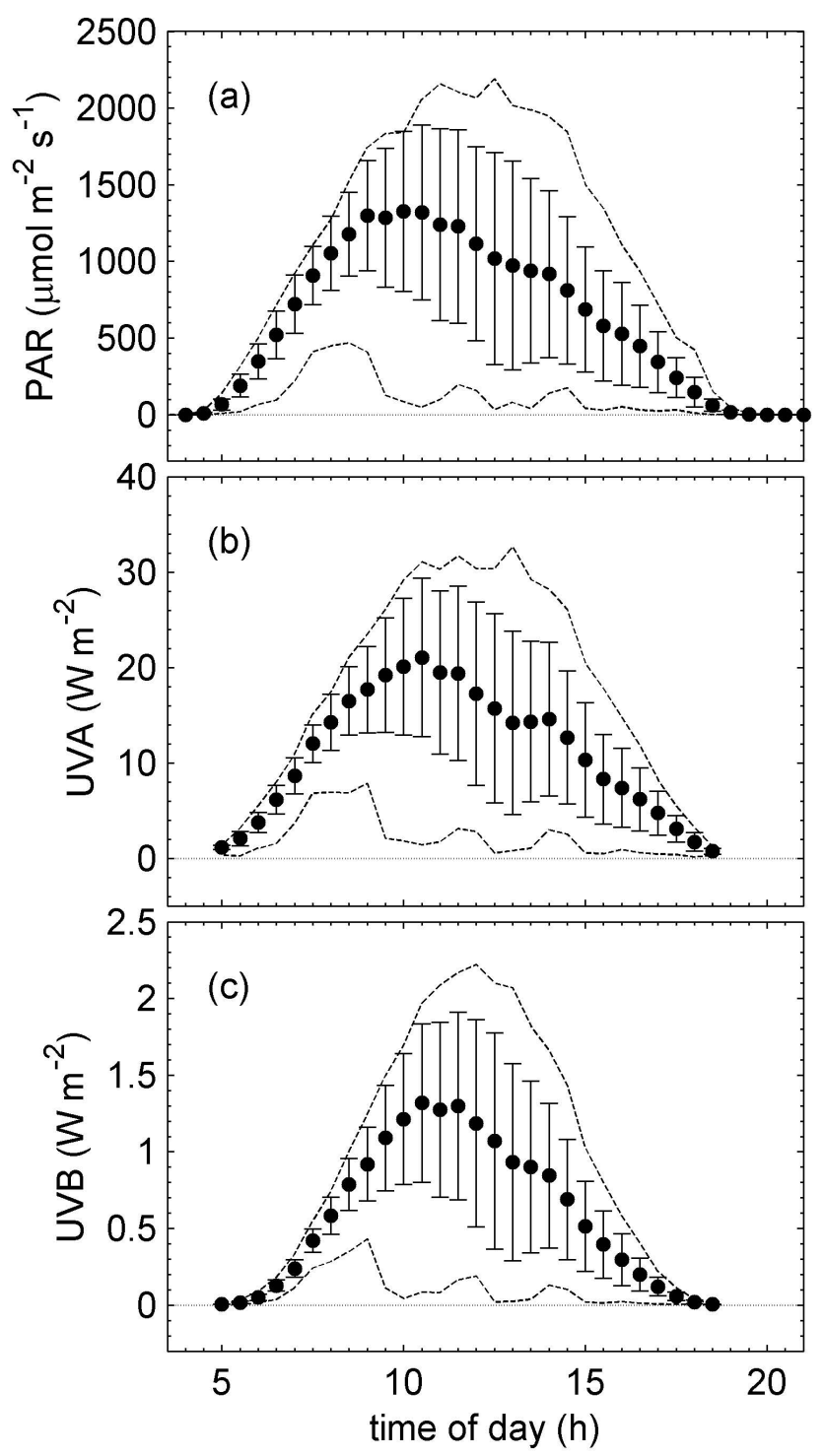

Fig. 3. Diel time course of above-canopy radiant flux densities (a) photosynthetically active radiation, (b) UVA (in the range 315$363 \mathrm{~nm})$, and (c) UVB $(286.5-315 \mathrm{~nm})$ irradiance. The data points show the mean over the 43 days of the study, error bars are \pm 1 standard deviation, and the dashed lines show the observed ranges for each time period. Note that the UVA sub-range $363-400 \mathrm{~nm}$ is not covered by these observations (Fig. 1), so the actual UVA irradiances were likely higher by a factor of 2 than those shown.

It is well-known that $\mathrm{CH}_{4}$ production occurs in anaerobic soil conditions. There were no abrupt changes in $\mathrm{CH}_{4}$ associated with precipitation events in the present study, although there is some indication of a baseline methane increase 12 days following many precipitation events (Fig. 2c and d). Rainstorms later in the season that increased soil moisture (days 208-210) did not substantially increase the $\mathrm{CH}_{4}$ baseline. While the soils were never saturated during the study, anaerobic micro-sites (Sey et al., 2008) were likely present within soil aggregates following the rain events. If $\mathrm{CH}_{4}$ was produced in soil aggregates it was likely consumed before diffusing to the forest air.

Scientists have observed diel patterns in $\mathrm{CH}_{4}$ within forests, with highest $\mathrm{CH}_{4}$ mole fractions at night, and diel amplitudes of 6-100 $\mathrm{nmol} \mathrm{mol}^{-1}$ (Shipham et al., 1998a; Simpson et al., 1999). We observed some periods of diel patterning in $\mathrm{CH}_{4}$ (Fig. 2d, days 181-185), but most of the record did not show it. In general, $\mathrm{CH}_{4}$ mole fractions within the canopy were similar to those above the canopy, but $\mathrm{CH}_{4}$ near the soil surface tended to be lower regardless of time of day. This was likely caused by soil $\mathrm{CH}_{4}$ consumption. The common diel pattern in $\mathrm{CO}_{2}$ (e.g., Jarvis et al., 1997) was caused by a consistent respiratory source (from soils always and from foliage at night) coupled with changes in atmospheric stability. Stability should also influence $\mathrm{CH}_{4}$, but the lack of significant diel pattern (Fig. 2d) suggests that additional factors were responsible for the day-to-day variability of $\mathrm{CH}_{4}$ in the air at the Niwot Ridge forest.

The wind direction in summer at the Niwot Ridge forest was bimodal, with relatively clean air flowing over the Continental Divide from the west at night, and a daytime reversal (Fig. 4). Above-canopy winds were primarily westerly (night) or easterly (midday). Early morning and late afternoon winds were usually westerly. Below-canopy winds were primarily westerly at night, but quite variable in direction during the day (Fig. 4c). The daily wind direction reversal was caused by a well-known regional mountain-plain wind system at this location (Brazel and Brazel, 1983).

The Niwot Ridge forest is situated near the eastern edge of the Rocky Mountains where they meet the Great Plains of the United States. The forest is roughly $60 \mathrm{~km}$ northwest of a large urban region on the plains (the Denver, Colorado, metropolitan area). A series of experiments focused on photochemical processes in air established that pollutants from the Denver urban area can be transported to the Niwot Ridge forest by easterly winds in summer (Roberts et al., 1985; Parrish et al., 1990, 1991). Although $\mathrm{CH}_{4}$ was not measured in those studies, carbon monoxide at Niwot Ridge tends to be higher during summer easterly winds (Parrish et al., 1991). In general, the highest $\mathrm{CH}_{4}$ observed during the present study was associated with daytime easterly flow (Fig. 4a). High $\mathrm{CH}_{4}$ periods were strongly correlated with high $\mathrm{CO}$ content (Fig. 5), at both the forest and the tundra sites, during summer 2007 and also in the longer record. Similar correlations between $\mathrm{CH}_{4}$ and anthropogenic hydrocarbon pollutants have been observed in long-term records at Harvard Forest, Massachusetts (Shipham et al., 1998b), suggesting an anthropogenic origin for elevated $\mathrm{CH}_{4}$ events. Combined with the Niwot Ridge air chemistry studies already mentioned, the data in Fig. 5 are strong evidence that the day to day variability in $\mathrm{CH}_{4}$ observed during our study (Fig. 2d) was caused by regional transport. High $\mathrm{CH}_{4}$ events such as days 200, day 207, and day 212 were probably urban in origin and likely not caused by local biological production 


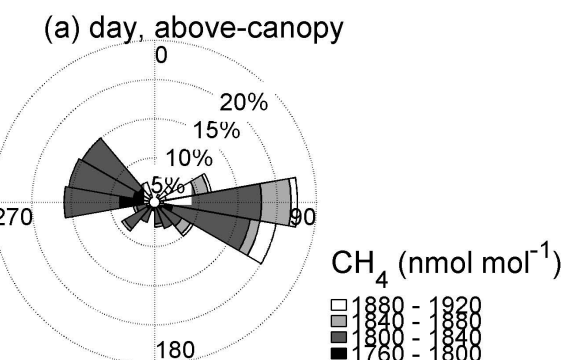

(c) day, below-canopy

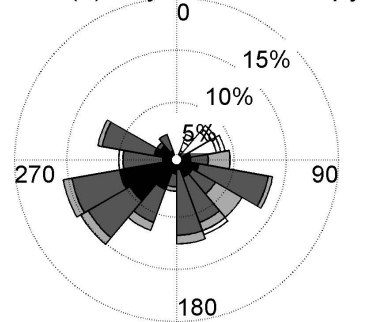

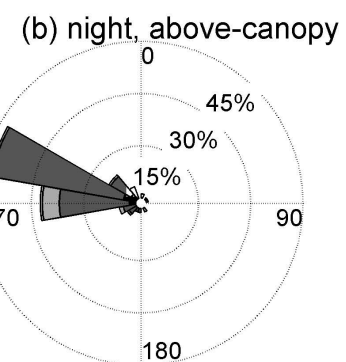

(d) night, below-canopy

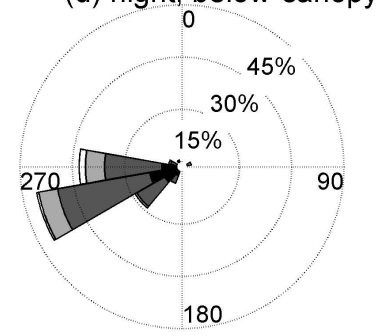

Fig. 4. Wind roses and methane mole fractions during the study. Data are shown for day (a) and (c) and night (b) and (d) separately for above-canopy ( $\mathrm{a}$ and b, $21.5 \mathrm{~m}$ wind and $21.5 \mathrm{~m} \mathrm{CH}_{4}$ ) and below-canopy (c and d, $2.56 \mathrm{~m}$ wind, $1 \mathrm{~m} \mathrm{CH}_{4}$ ). The radius of each wedge shows the percentage of time that the wind blew from the direction indicated (in $20^{\circ}$ bins), and the wedges are divided into 4 gray-scale bins based on the observed $\mathrm{CH}_{4}$ mole fraction during that period. The area of each gray-scale portion of the wedge is proportional to the relative frequency that the $\mathrm{CH}_{4}$ mole fraction was observed in the indicated range. The wind percentage scales differ in the panels.

within the forest. Although the easterly flow pattern was common, not all easterly flow was associated with high $\mathrm{CH}_{4}$ (Fig. 4), presumably due to variability of air mass origin, aging, or route of transport.

\subsection{Below-canopy gradients and soil fluxes}

Our principal aim was to assess the presence of local forest $\mathrm{CH}_{4}$ sources and sinks, and there are several possible ways to address this aim. Although the respiratory soil $\mathrm{CO}_{2}$ source was associated with a consistent diel pattern, the diel pattern was largely absent for $\mathrm{CH}_{4}$, and variability in mole fraction is not a robust indicator of fluxes. Others have used $\mathrm{CH}_{4}$ profiles within forests and a canopy-layer budget method to assess forest $\mathrm{CH}_{4}$ source strength (do Carmo et al., 2006). Inverse Lagrangian analysis is probably the best way to assess the vertical distribution of fluxes within a canopy, and has been used for $\mathrm{CH}_{4}$ in rice canopies (Leuning et al., 2000). However, given the complexities of radiative transport in clumped conifer canopies (Baldocchi and Collineau, 1994), the central importance of UV radiation for aerobic $\mathrm{CH}_{4}$ production (McLeod et al., 2008; Vigano et al., 2008; Messenger et al., 2009), and the non-homogeneous nature of the Niwot Ridge canopy, such an analysis is beyond the scope of this paper.

We chose to use gradients and daytime excess (see Methods) to assess whether soils and vegetation at the site were sources or sinks for $\mathrm{CH}_{4}$. We cannot, however, use observed gradients to calculate meaningful $\mathrm{CH}_{4}$ fluxes during every 30-min measurement period. Within plant canopies,

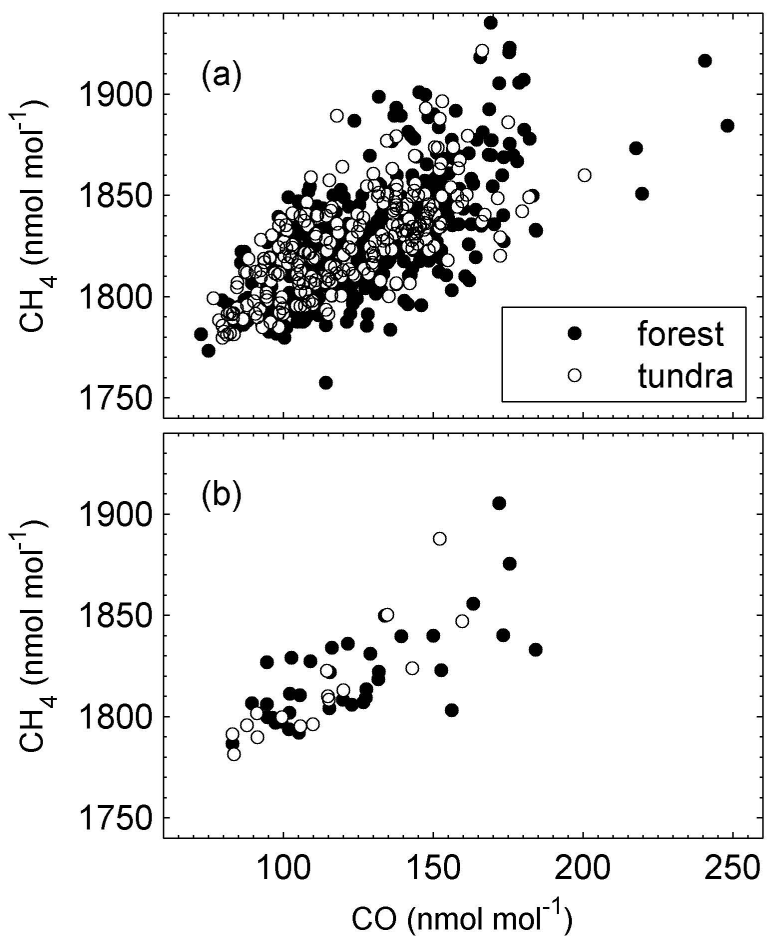

Fig. 5. (a) Methane and carbon monoxide mole fractions at the forest and tundra sites during September 2005 to October 2007 and (b) for the subset of time during summer 2007. 
the direction of trace gas flux can sometimes be opposite the direction of the mole fraction gradient, and the assumptions on which flux-gradient theory is based are often violated (Raupach, 1979; Denmead and Bradley, 1985; Cellier and Brunet, 1992). However, over time the direction of the fluxes and gradients should converge in their means, otherwise mass could not be conserved. For example, a persistent soil $\mathrm{CH}_{4}$ sink should have, in a mean sense, a downward flux direction and a matching gradient, with lower $\mathrm{CH}_{4}$ nearer the ground. Similarly, a persistent canopy source of $\mathrm{CH}_{4}$ (such as from aerobic foliar emission) should on average have elevated $\mathrm{CH}_{4}$ in the canopy relative to the above-canopy air.

In the following discussion, we present the frequency distributions of gradients (and of daytime excess) to assess the direction and magnitude of fluxes. Both $\mathrm{CO}_{2}$ and $\mathrm{CH}_{4}$ data are presented because many readers are familiar with spatial and temporal patterns of $\mathrm{CO}_{2}$ in forest air and can use that knowledge to interpret $\mathrm{CH}_{4}$ patterns (which are less wellunderstood). We first describe two example periods in detail, and then show the full distributions of observed gradients. Shown in Fig. 6 are sample night and day profiles for $\mathrm{CO}_{2}$ and $\mathrm{CH}_{4}$, each measured within a 30-minute period. The $\mathrm{CO}_{2}$ profile at night (Fig. 6a) showed high $\mathrm{CO}_{2}$ near the ground $\left(\sim 450 \mu \mathrm{mol} \mathrm{mol}^{-1}\right)$, decreasing with height to a minimum above the canopy $\left(\sim 390 \mu \mathrm{mol} \mathrm{mol}^{-1}\right)$. The gradients near the ground and within the canopy are shown as solid lines (regressions through each of the 3 groups of inlets). The sign convention used is that a negative slope in the lines shown in Fig. 6 (such as for $\mathrm{CO}_{2}$ at night, panel a) corresponds to a positive gradient $\left(\mu \mathrm{mol} \mathrm{mol}^{-1} \mathrm{~m}^{-1}\right)$ in the figures that follow. By this convention a positive gradient indicates a source, and a negative gradient a sink. The night $\mathrm{CO}_{2}$ profile shown reflects a soil source, and there was a $\mathrm{CH}_{4}$ sink in the soil (based on the direction of each gradient in the near-ground inlets). The $\mathrm{CO}_{2}$ gradient within the canopy indicates a $\mathrm{CO}_{2}$ source, which includes respiration from soil, living woody tissues, and leaf (needle) dark respiration. Note, however, if we did not know the foliage was a source of $\mathrm{CO}_{2}$ at night, the profile observed within the canopy (Fig. 6a) might result from the $\mathrm{CO}_{2}$ source in the soil. In contrast, the apparent canopy $\mathrm{CH}_{4}$ source (in this example) cannot be attributed to the local soils since they were a sink (see opposite direction of gradients in canopy and near the ground in Fig. 6b).

During the daytime period shown, the soils remained a $\mathrm{CO}_{2}$ source (Fig. 6c), and a $\mathrm{CH}_{4}$ sink (Fig. 6d). The negative $\mathrm{CH}_{4}$ gradient within the canopy could indicate 1) a soil $\mathrm{CH}_{4}$ sink and no canopy exchange of $\left.\mathrm{CH}_{4}, 2\right)$ a soil $\mathrm{CH}_{4}$ sink and a canopy $\mathrm{CH}_{4}$ sink, or 3 ) a dominant soil $\mathrm{CH}_{4}$ sink and a smaller canopy $\mathrm{CH}_{4}$ source, with relative magnitudes such that the combined net $\mathrm{CH}_{4}$ flux is a sink. Analysis of gradients during individual measurement periods cannot reliably be used to distinguish between these possibilities. $\mathrm{CO}_{2}$ within the canopy during the daytime was lowest at the middle canopy inlet (Fig. 6c), which illustrates a potential prob-
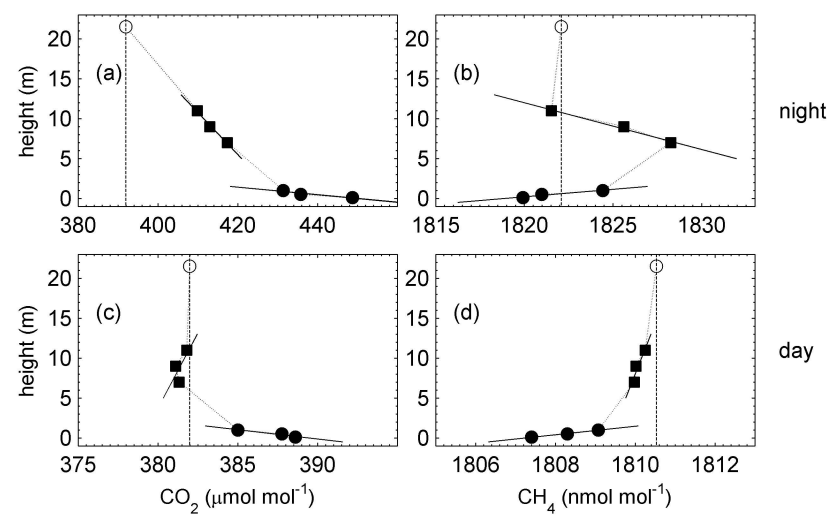

Fig. 6. Example vertical profiles of carbon dioxide (a) and (c) and methane (b) and (d) mole fractions. The top panels show a stable night period (day 192.85) and the bottom panels show a high-UV daytime period (day 192.44). The inlets near the ground are indicated with filled circles, those within the vegetation canopy with filled squares, and above-canopy with an open circle. The vertical dashed line represents the above-canopy observation and the solid lines show linear regressions through the canopy or ground inlets separately. The slopes of the regression lines are used to calculate the gradients of each trace gas for each 30-min measurement period shown in Figs. 7 and 8.

lem with analysis of small within-canopy gradients. While the photosynthetic $\mathrm{CO}_{2}$ sink in the canopy was clear (since the within-canopy $\mathrm{CO}_{2}$ was consistently lower than aboveand below-canopy at all 3 canopy measurement heights), the regression line at times like these might have either a positive or negative slope based on the relative drawdown at each measurement height, because the gradient is not consistent in direction. In some of the figures that follow, we present both within-canopy daytime gradients and daytime excess (within-canopy mean relative to above-canopy) to clearly indicate the pattern in the canopy.

The frequency distributions of all observed gradients at the 3 near-ground inlets are shown in Fig. 7. Daytime and nighttime periods and subsets of these (high UV or stable nights) are shown separately. In general, gradients of $\mathrm{CO}_{2}$ near the ground were positive, both during the day (Fig. 7a, mean $\pm 1 \mathrm{SD}$ of the daytime gradients was $17.7 \pm 14.2 \mu \mathrm{mol} \mathrm{mol}^{-1} \mathrm{~m}^{-1}$ ) and at night (Fig. 7c, $20.5 \pm 12.7 \mu \mathrm{mol} \mathrm{mol}^{-1} \mathrm{~m}^{-1}$ ), with a large number of profiles measured for each case (number of profiles, $n$, is indicated above each panel). The $\mathrm{CO}_{2}$ gradient distributions were positively skewed. $\mathrm{CH}_{4}$ gradients near the ground were generally negative during the day (Fig. 7e, $-5.4 \pm 5.1 \mathrm{nmol} \mathrm{mol}^{-1} \mathrm{~m}^{-1}$ ) and at night (Fig. $7 \mathrm{~g},-6.2 \pm 8.2 \mathrm{nmol} \mathrm{mol}^{-1} \mathrm{~m}^{-1}$ ), and the distributions were strongly negatively skewed, indicating a persistent net soil sink for $\mathrm{CH}_{4}$. Both $\mathrm{CO}_{2}$ and $\mathrm{CH}_{4}$ fluxes were strong enough that the near-ground gradients persisted during the day when greater turbulent mixing had the potential to erase them. 

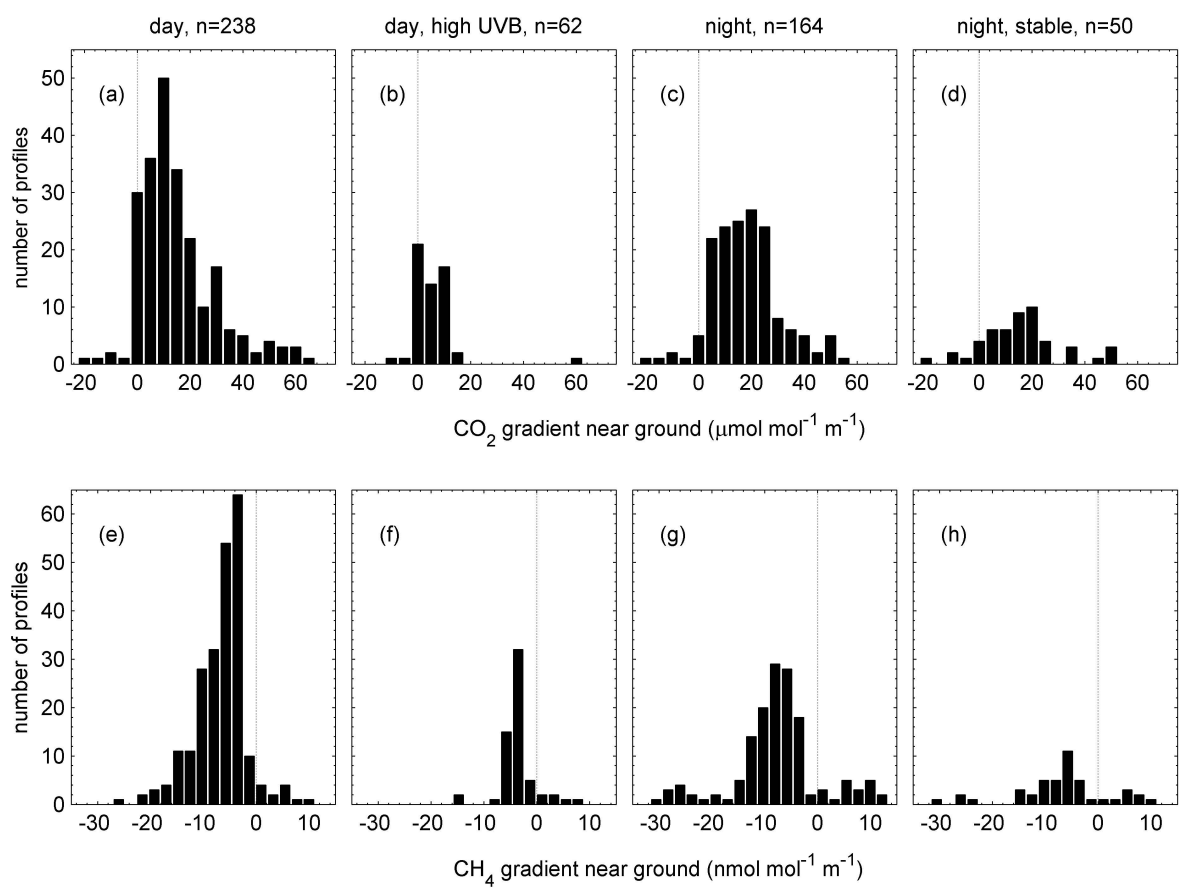

Fig. 7. Frequency distributions of observed $\mathrm{CO}_{2}$ (top) and $\mathrm{CH}_{4}$ (bottom) gradients using the near-ground inlets $(0.1,0.5$, and $1 \mathrm{~m}$ height). The data are separated into all daytime periods (a) and (e), daytime periods with UVB flux density greater than $1 \mathrm{~W} \mathrm{~m}^{-2}$ (b) and (f), all nighttime periods (c) and (g), and stable nighttime periods with friction velocity $<0.15 \mathrm{~m} \mathrm{~s}^{-1}$ (d) and (h). Vertical dotted lines show the zero gradient. The sign convention means positive gradients indicate a source, negative gradients a sink. The titles on the 4 top panels also apply to the lower 4 panels.

The soil-source $\mathrm{CO}_{2}$ gradient pattern has been observed in summer-long mean diel patterns at the Niwot Ridge forest (Bowling et al., 2005), and this is no surprise given the respiratory production of $\mathrm{CO}_{2}$ by soil organisms, including roots. The soil methane sink, which is common in temperate forest soils (Smith et al., 2000; Le Mer and Roger, 2001), is most likely due to activity of methanotrophs.

If we assume scalar similarity between $\mathrm{CO}_{2}$ and $\mathrm{CH}_{4}$, the gradients of each gas near the ground should be related to the respective fluxes by the same eddy diffusivity. This is the basis of the flux-gradient method for estimation of fluxes (Baldocchi et al., 1988), and can be formalized as:

$$
\begin{aligned}
F_{\mathrm{CO}_{2}} & =-K \frac{d \mathrm{CO}_{2}}{d z} \\
F_{\mathrm{CH}_{4}} & =-K \frac{d \mathrm{CH}_{4}}{d z} \\
F_{\mathrm{CH}_{4}} & =-\left[\frac{F_{\mathrm{CO}_{2}}}{d \mathrm{CO}_{2} / d z}\right]\left[\frac{d \mathrm{CH}_{4}}{d z}\right]
\end{aligned}
$$

where $F_{\mathrm{CO}_{2}}$ and $F_{\mathrm{CH}_{4}}$ represent the flux of each gas, $d \mathrm{CO}_{2} / d z$ and $d \mathrm{CH}_{4} / d z$ the summer mean daytime gradients of each gas near the ground, and $K$ the eddy diffusivity. Equation (3) allows us to estimate a summer mean flux of $\mathrm{CH}_{4}$ from a known summertime $\mathrm{CO}_{2}$ flux and mean measured gradients of each trace gas. Midsummer soil $\mathrm{CO}_{2}$ efflux in the Niwot Ridge forest is typically in the range 4-6 $\mu \mathrm{mol} \mathrm{m}^{-2} \mathrm{~s}^{-1}$, and at the soil moisture levels of the present study, around $4 \mu \mathrm{mol} \mathrm{m}^{-2} \mathrm{~s}^{-1}$ (Scott-Denton et al., 2003; Scott-Denton et al., 2006). Using this value and the mean daytime gradients of $17.7 \mu \mathrm{mol} \mathrm{CO}_{2} \mathrm{~mol}^{-1} \mathrm{~m}^{-1}$ and $-5.4 \mathrm{nmol} \mathrm{CH}_{4} \mathrm{~mol}^{-1} \mathrm{~m}^{-1}$ from Fig. 7, with Eq. (3) we estimate the magnitude of the soil methane sink as $1.7 \mathrm{mg} \mathrm{CH}_{4} \mathrm{~m}^{-2} \mathrm{~d}^{-1}$, (for comparison with studies below, this equates to $70 \mu \mathrm{g} \mathrm{CH}_{4} \mathrm{~m}^{-2} \mathrm{~h}^{-1}$ or $17 \mathrm{~g} \mathrm{CH}_{4} \mathrm{ha}^{-1} \mathrm{~d}^{-1}$ ).

We are unaware of any previous reports of $\mathrm{CH}_{4}$ uptake by high-elevation subalpine forest soils. This is clearly an approximation, but should be of the correct order of magnitude. Our estimate is well within the range of published values for upland forest soil methanotrophy. In a comprehensive review of emission and consumption of methane by soils, Le Mer and Roger (2001) reported the median $\mathrm{CH}_{4}$ uptake flux for primarily tropical and temperate forest soils was $9.9 \mathrm{~g} \mathrm{CH}_{4} \mathrm{ha}^{-1} \mathrm{~d}^{-1}$, with a range of 0.16 to $1659 \mathrm{CH}_{4} \mathrm{ha}^{-1} \mathrm{~d}^{-1}$. $\mathrm{CH}_{4}$ uptake by temperate coniferous and deciduous forest soils in Europe tends to be in the range $0-100 \mu \mathrm{g} \mathrm{CH}_{4} \mathrm{~m}^{-2} \mathrm{~h}^{-1}$ (Smith et al., 2000). The soils at Niwot Ridge are always saturated during and shortly after the period of snowmelt (Monson et al., 2006; Molotch et al., 2007), usually leading to overland flow (Hood et al., 2003). The snowmelt time period was not covered by our observations, and local soil $\mathrm{CH}_{4}$ production is quite possible under those conditions. 

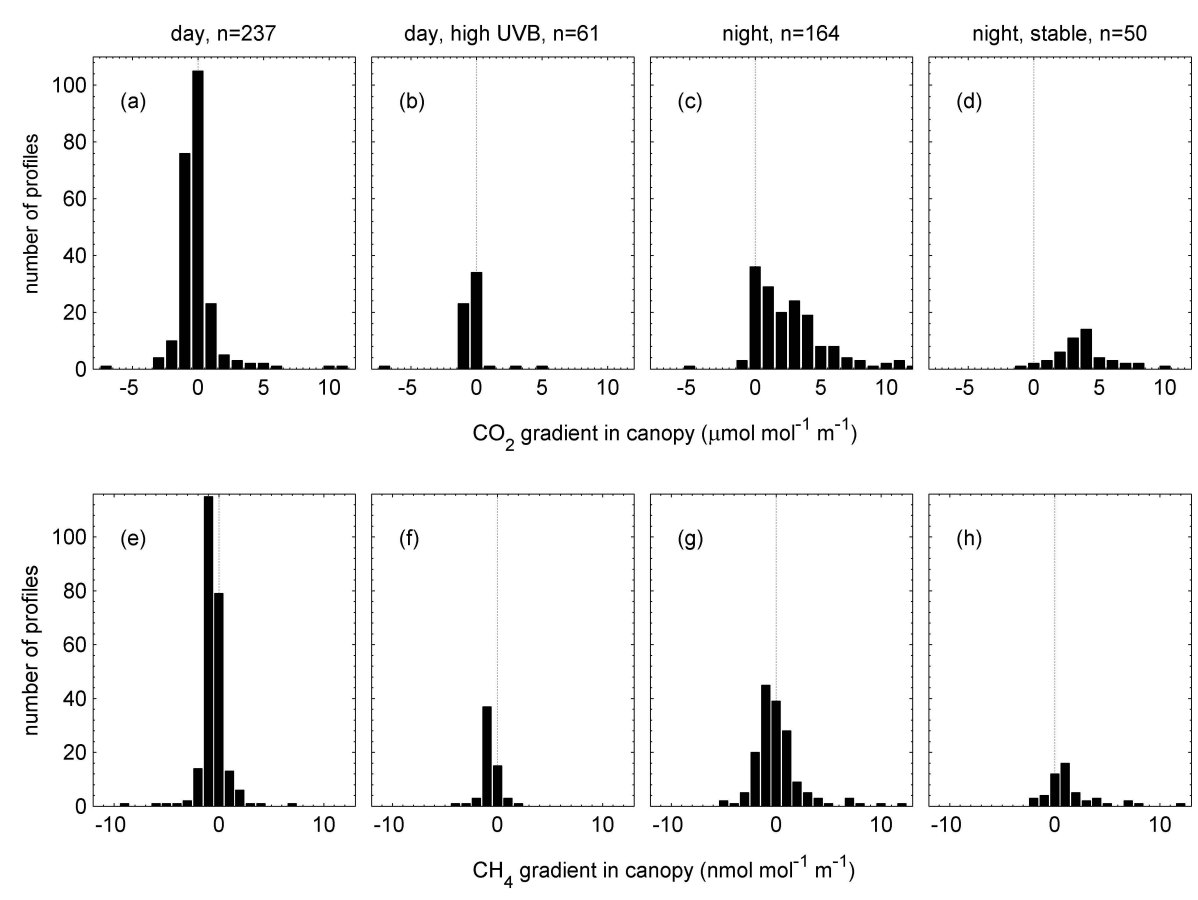

Fig. 8. Same as Fig. 7, but for the within-canopy inlets (7, 9, 11m height).

\subsection{Within-canopy gradients, daytime excess, and canopy fluxes}

Gradients of both gases were generally smaller within the vegetation canopy (compared to near the ground) under all conditions (Fig. 8). At night, the within-canopy $\mathrm{CO}_{2}$ gradient was generally positive as expected for a combined soil and canopy respiratory source. The nocturnal $\mathrm{CH}_{4}$ gradients observed in the canopy were not principally positive or negative, but more evenly distributed (Fig. 8g). Under stable nighttime conditions usually associated with katabatic flow, the Niwot Ridge forest experiences vertical flow stratification. Tracer experiments and isotopic studies have shown under these stable conditions the air within the vegetation canopy does not mix with air near the soil, and so canopy air should be indicative of canopy physiological processes (Yi et al., 2005; Schaeffer et al., 2008a). The study of Schaeffer and colleagues used several meteorological parameters to indicate these conditions; here we use only the friction velocity $u *$. The within-canopy $\mathrm{CO}_{2}$ gradient on very stable nights was small and positive $\left(4.4 \pm 2.5 \mu \mathrm{mol} \mathrm{mol}^{-1} \mathrm{~m}^{-1}\right)$, indicating a respiratory source. The nocturnal $\mathrm{CH}_{4}$ gradient under very stable conditions was small and positive $\left(2.0 \pm 2.7 \mathrm{nmol} \mathrm{mol}^{-1} \mathrm{~m}^{-1}\right.$, Fig. $\left.8 \mathrm{~h}\right)$, and also indicated a possible weak canopy source at times. This methane source cannot be attributed to the local soils, since they were clearly a $\mathrm{CH}_{4}$ sink (Fig. 7).

There are several possible explanations for the apparent nocturnal $\mathrm{CH}_{4}$ source within the canopy. Aerobic foliar emission at night seems unlikely since UV radiation ap- pears to be required for plant emission (McLeod et al., 2008; Vigano et al., 2008; Messenger et al., 2009). Plants apparently can emit $\mathrm{CH}_{4}$ without UV radiation, but at very low rates unless exposed to extremely high temperatures (Vigano et al., 2008) or following foliar injury (Wang et al., 2009), neither of which apply in this case. In a very wet forest with thick moss mats, epiphytes, and termites in the canopy, anaerobic microbial emission is possible (do Carmo et al., 2006), but our forest has a dry canopy except immediately after rain events, and no similar organic microbial habitat within the canopy or termites. The possibility exists for deep soil anaerobic microbial $\mathrm{CH}_{4}$ production, followed by transport through the stem and out through the stomata, but this mechanism is highly speculative at present except for flood-adapted species that possess aerenchyma (Rusch and Rennenberg, 1998; Terazawa et al., 2007; Megonigal and Guenther, 2008). The evening wind direction reversal from somewhat-polluted to relatively-cleaner flow at Niwot Ridge (Fig. 4) could leave lower $\mathrm{CH}_{4}$ above the canopy than within at night, and the apparent $\mathrm{CH}_{4}$ "source" in the canopy could simply reflect this external forcing. We attempted to find evidence for this scenario in our data based on several analyses of wind speed and direction, continuity of wind direction, and storage fluxes, but were unsuccessful. Wetlands in the region are known anaerobic sources of $\mathrm{CH}_{4}$ (Wickland et al., 2001; Chimner and Cooper, 2003). The most likely reason we observed a positive $\mathrm{CH}_{4}$ gradient in the canopy under very stable conditions (Fig. 8h) is due to horizontal transport from upwind wetland sources. There are several ponds and boggy areas in the predominant nighttime flow direction 
within $1-3 \mathrm{~km}$ distance. The flow stratification pattern on stable nights already discussed (Yi et al., 2005; Schaeffer et al., 2008a) probably leads to horizontal transport from these sources.

Within the daytime canopy under high UV radiation, photosynthetic drawdown of $\mathrm{CO}_{2}$ was apparent (Fig. 8b), and $\mathrm{CH}_{4}$ gradients were small and usually negative (Fig. 8f). As discussed previously, the sign of the gradient within the canopy in the short term might not correctly reflect the source/sink nature of canopy physiological processes. Shown in Fig. 9 are the frequency distributions of daytime excess $\mathrm{CO}_{2}$ and $\mathrm{CH}_{4}$ within the canopy. Generally, the daytime excess indicated sinks for both gases, for all daytime periods, and particularly for high UV periods. On average for the 62 profiles with the highest UV irradiance, the $\mathrm{CH}_{4}$ mole fraction within the canopy was $-0.93 \pm 4.0 \mathrm{nmol} \mathrm{mol}^{-1}$ (mean $\pm \mathrm{SD}$ of the distribution in Fig. 9d) lower than above the canopy (Fig. 9d). The mean $\mathrm{CO}_{2}$ drawdown by the canopy photosynthetic sink was $-0.8 \pm 1.3 \mu \mathrm{mol} \mathrm{mol}^{-1}$. While these means were not different from zero, both distributions were strongly negatively skewed, implying a canopy (or possibly soil, in the case of $\mathrm{CH}_{4}$ ) sink for both gases.

The fact that negative $\mathrm{CO}_{2}$ gradients (Fig. 8b) and negative daytime $\mathrm{CO}_{2}$ excess (Fig. 9b) were detectable in the canopy under high UV irradiance causes us to conclude that turbulence was not sufficient to mask the $\mathrm{CO}_{2}$ sink. Clear evidence of net photosynthesis in the canopy was obtained, and this provides some confidence that a foliar $\mathrm{CH}_{4}$ emission source, if present, would be detected (or smaller than our method can resolve). As discussed, it is possible that the canopy could be a source of $\mathrm{CH}_{4}$ that is masked by a stronger soil $\mathrm{CH}_{4}$ sink, but the data in Figs. 7-9 strongly indicate that the vegetation canopy at Niwot Ridge is at most a very weak $\mathrm{CH}_{4}$ source, and the Niwot Ridge forest during our study acted as a net sink for atmospheric methane.

To our knowledge only Vigano et al. (2008) have attempted to find aerobic $\mathrm{CH}_{4}$ emission from conifers, and only from the single tree species Pinus ponderosa, which was found to be an emitter. Our study provides evidence that aerobic foliar $\mathrm{CH}_{4}$ emission from the dominant conifer species at Niwot Ridge (Pinus contorta, Picea engelmannii, and Abies lasiocarpa) is minimal, and likely does not need to be accounted for in large-scale emission inventories.

We caution, though, that Wang et al. (2009) have recently shown that of ten congeneric Artemisia species studied, only one species emitted $\mathrm{CH}_{4}$ without physical injury to the plant. Hence, demonstrated emission by $P$. ponderosa under UV irradiation (Vigano et al., 2008) does not necessarily imply that all conifers emit $\mathrm{CH}_{4}$. Similarly, the absence of evidence for strong foliar emission in our forest does not necessarily mean that no conifer forests emit methane from the trees. Given the growing body of literature documenting aerobic methane emission from plants, more work is clearly needed to assess the general phenomenon of methane emission across plant
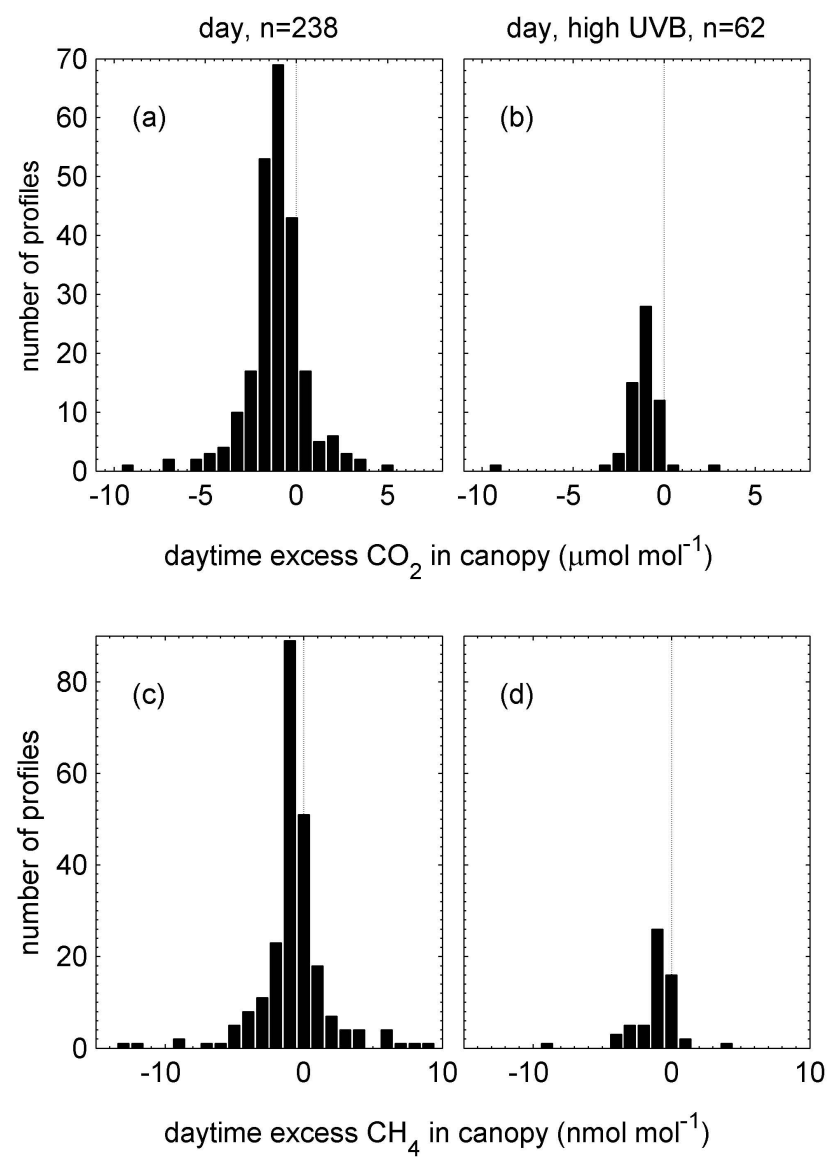

Fig. 9. Frequency distributions of the daytime excess $\mathrm{CO}_{2}$ (top) and $\mathrm{CH}_{4}$ (bottom) within the canopy, for daytime periods only. Daytime excess was calculated as the mean of the mole fractions at the 3 canopy inlets $(7,9$, and $11 \mathrm{~m})$ minus the mole fraction above-canopy $(21.5 \mathrm{~m})$ for a given 30 -min period. Negative values indicate lower $\mathrm{CO}_{2}$ or $\mathrm{CH}_{4}$ within the canopy compared to above it (a sink, such as during strong photosynthetic drawdown of $\mathrm{CO}_{2}$ ). Positive values are suggestive of a canopy source. Data are divided into all daytime periods and high UVB periods as in Figs. 7 and 8 .

taxa, and to determine the general ecological significance of plant emission of methane in intact ecosystems.

\section{Summary}

Patterns of biosphere-atmosphere methane and carbon dioxide exchange were examined in a high-elevation subalpine forest using canopy profile observations over a 6-week summer period. Variability in the $\mathrm{CH}_{4}$ mole fraction of forest air was related to a mountain-plain wind system and influenced by air mass transport from the Denver, Colorado, urban area. Local soils were a persistent $\mathrm{CH}_{4}$ sink during the study period. No evidence was found for substantial emission of $\mathrm{CH}_{4}$ from the foliar vegetation, even under high UV irradiance. We cannot rule out the possibility of a canopy source given 
the observed soil sink, but the magnitude of such a vegetation source in this forest must be very weak if it exists at all.

Acknowledgements. Thanks to Ed Dlugokencky and Patricia Lang for calibrating standards and $\mathrm{CH}_{4}$ flask measurements, Paul Novelli for CO flask measurements, Andrew Crotwell and Doug Guenther for loaning scientific equipment, and Sean Schaeffer for assistance in the field. We are grateful to Patrick Disterhoft and the NEUBrew project members for freely providing UV data. Several colleagues contributed helpful ideas and discussion at AGU including Pat Crill, Gunnar Schade, Torben Christensen, and Todd Rosenstiel. Primary funding for this work was provided by U.S. Dept. of Energy, Office of Science (BER), Grant No. DE-FG02-04ER63904 (to DRB and JBM). We acknowledge additional support from the National Oceanic and Atmospheric Administration Ernest F. Hollings Undergraduate Scholarship Program (to MER) administered by Oak Ridge Institute for Science and Education under a contract between the U.S. Department of Energy and Oak Ridge Associated Universities, from a grant from DOE National Institute for Climatic Change Research (NICCR) Western region (to RKM), and NSF grant DEB 0423662 to the Niwot Ridge LTER program.

Edited by: G. Wohlfahrt

\section{References}

Apel, K. and Hirt, H.: Reactive oxygen species: Metabolism, oxidative stress, and signal transduction, Ann. Rev. Plant Biol., 55, 373-399, 2004.

Baldocchi, D. D. and Collineau, S.: The physical nature of solar radiation in heterogeneous canopies: spatial and temporal attributes, in: Exploitation of Environmental Heterogeneity, edited by: Pearcy, R. W. and Caldwell, M. M., Academic Press, San Diego, 21-71, 1994.

Baldocchi, D. D., Hicks, B. B., and Meyers, T. P.: Measuring biosphere-atmosphere exchanges of biologically related gases with micrometerological methods, Ecology, 69, 1331-1340, 1988.

Beerling, D. J., Gardiner, T., Leggett, G., McLeod, A., and Quick, W. P.: Missing methane emissions from leaves of terrestrial plants, Glob. Change Biol., 14, 1821-1826, 2008.

Bergamaschi, P., Frankenberg, C., Meirink, J. F., Krol, M., Dentener, F., Wagner, T., Platt, U., Kaplan, J. O., Korner, S., Heimann, M., Dlugokencky, E. J., and Goede, A.: Satellite chartography of atmospheric methane from SCIAMACHY on board ENVISAT: 2. Evaluation based on inverse model simulations, J. Geophys. Res., 112, D02304, doi:02310.01029/02006JD007268, 2007.

Bousquet, P., Ciais, P., Miller, J. B., Dlugokencky, E. J., Hauglustaine, D. A., Prigent, C., Van der Werf, G. R., Peylin, P., Brunke, E. G., Carouge, C., Langenfelds, R. L., Lathiere, J., Papa, F., Ramonet, M., Schmidt, M., Steele, L. P., Tyler, S. C., and White, J.: Contribution of anthropogenic and natural sources to atmospheric methane variability, Nature, 443, 439-443, 2006.

Bowling, D. R., Burns, S. P., Conway, T. J., Monson, R. K., and White, J. W. C.: Extensive observations of $\mathrm{CO}_{2}$ carbon isotope content in and above a high-elevation subalpine forest, Global Biogeochem. Cy., 19, GB3023, doi:3010.1029/2004GB002394, 2005.
Brazel, A. J. and Brazel, S. W.: Summer diurnal wind patterns at 3000m surface level, Front Range, Colorado, USA Physical Geography, 4, 53-61, 1983.

Bruggemann, N., Meier, R., Steigner, D., Zimmer, I., Louis, S., and Schnitzler, J. P.: Nonmicrobial aerobic methane emission from poplar shoot cultures under low-light conditions, New Phytol., 182, 912-918, 2009.

Cao, G. M., Xu, X. L., Long, R. J., Wang, Q. L., Wang, C. T., Du, Y. G., and Zhao, X. Q.: Methane emissions by alpine plant communities in the Qinghai-Tibet Plateau, Biol. Lett., 4, 681684, 2008.

Cellier, P. and Brunet, Y.: Flux-gradient relationships above tall plant canopies, Agr. Forest Meteorol., 58, 93-117, 1992.

Chimner, R. A. and Cooper, D. J.: Carbon dynamics of pristine and hydrologically modified fens in the southern Rocky Mountains, Can. J. Bot., 81, 477-491, 2003.

Cicerone, R. J. and Oremland, R. S.: Biogeochemical aspects of atmospheric methane, Global Biogeochem. Cy., 2, 299-327, 1988.

Denman, K. L., Brasseur, G., Chidthaisong, A., Ciais, P., Cox, P. M., Dickinson, R. E., Hauglustaine, D., Heinze, C., Holland, E., Jacob, D., Lohmann, U., Ramachandran, S., da Silva Dias, P. L., Wofsy, S. C., and Zhang, X.: Couplings between changes in the climate system and biogeochemistry, in: Climate Change 2007: The Physical Science Basis, edited by: Solomon, S., Qin, D., Manning, M., Chen, Z., Marquis, M., Averyt, K. B., Tignor, M., and Miller, H. L., Contribution of Working Group 1 to the Fourth Assessment Report of the Intergovernmental Panel on Climate Change, Cambridge University Press, Cambridge, United Kingdom and New York, NY, USA, 2007.

Denmead, O. T. and Bradley, E. F.: Flux-gradient relationships in a forest canopy, in: The Forest-Atmosphere Interaction, edited by: Hutchinson, B. A. and Hicks, B. B., Reidell, Norwell, MA, 421-442, 1985.

Dlugokencky, E. J., Houweling, S., Bruhwiler, L., Masarie, K. A., Lang, P. M., Miller, J. B., and Tans, P. P.: Atmospheric methane levels off: Temporary pause or a new steady-state?, Geophys. Res. Lett., 30, doi:10.1029/2003GL018126, 2003.

Dlugokencky, E. J., Steele, L. P., Lang, P. M., and Masarie, K. A.: The growth rate and distribution of atmospheric methane, J. Geophys. Res., 99, 17021-17043, 1994.

do Carmo, J. B., Keller, M., Dias, J. D., de Camargo, P. B., and Crill, P.: A source of methane from upland forests in the Brazilian Amazon, Geophys. Res. Lett., 33, L04809, doi:04810.01029/02005GL025436, 2006.

Dueck, T. A., de Visser, R., Poorter, H., Persijn, S., Gorissen, A., de Visser, W., Schapendonk, A., Verhagen, J., Snel, J., Harren, F. J. M., Ngai, A. K. Y., Verstappen, F., Bouwmeester, H., Voesenek, L. A. C. J., and van der Werf, A.: No evidence for substantial aerobic methane emission by terrestrial plants: a ${ }^{13} \mathrm{C}$-labelling approach, New Phytol., 175, 29-35, 2007.

Dutaur, L. and Verchot, L. V.: A global inventory of the soil $\mathrm{CH}_{4}$ sink, Global Biogeochem. Cy., 21, GB4013, doi:4010.1029/2006GB002734, 2007.

Etheridge, D. M., Steele, L. P., Francey, R. J., and Langenfelds, R. L.: Atmospheric methane between 1000 A.D. and present: Evidence of anthropogenic emissions and climatic variability, J. Geophys. Res., 103, 15979-15993, 1998.

Ferretti, D. F., Miller, J. B., White, J. W. C., Etheridge, D. M., Lassey, K. R., Lowe, D. C., Meure, C. M. M., Dreier, M. F., 
Trudinger, C. M., van Ommen, T. D., and Langenfelds, R. L.: Unexpected changes to the global methane budget over the past 2000 years, Science, 309, 1714-1717, 2005.

Ferretti, D. F., Miller, J. B., White, J. W. C., Lassey, K. R., Lowe, D. C., and Etheridge, D. M.: Stable isotopes provide revised global limits of aerobic methane emissions from plants, Atmos. Chem. Phys., 7, 237-241, 2007, http://www.atmos-chem-phys.net/7/237/2007/.

Forster, P., Ramaswamy, V., Artaxo, P., Berntsen, T., Betts, R., Fahey, D. W., Haywood, J., Lean, J., Lowe, D. C., Myhre, G., Nganga, J., Prinn, R., Raga, G., Schulz, M., and Van Dorland, R.: Changes in atmospheric constituents and in radiative forcing, in: Climate Change 2007: The Physical Science Basis, edited by: Solomon, S., Qin, D., Manning, M., Chen, Z., Marquis, M., Averyt, K. B., Tignor, M., and Miller, H. L., Contribution of Working Group 1 to the Fourth Assessment Report of the Intergovernmental Panel on Climate Change, Cambridge University Press, Cambridge, United Kingdom and New York, NY, USA, 2007.

Frankenberg, C., Bergamaschi, P., Butz, A., Houweling, S., Meirink, J. F., Notholt, J., Petersen, A. K., Schrijver, H., Warneke, T., and Aben, I.: Tropical methane emissions: A revised view from SCIAMACHY onboard ENVISAT, Geophys. Res. Lett., 35, L15811, doi:15810.11029/12008GL034300, 2008.

Hood, E., McKnight, D. M., and Williams, M. W.: Sources and chemical character of dissolved organic carbon across an alpine/subalpine ecotone, Green Lakes Valley, Colorado Front Range, United States, Water Resour. Res., 39, 1188, doi:1110.1029/2002WR001738, 2003.

Houweling, S., Rockmann, T., Aben, I., Keppler, F., Krol, M., Meirink, J. F., Dlugokencky, E. J., and Frankenberg, C.: Atmospheric constraints on global emissions of methane from plants, Geophys. Res. Lett., 33, L15821, doi:15810.11029/12006GL026162, 2006.

Houweling, S., van der Werf, G. R., Goldewijk, K. K., Rockmann, T., and Aben, I.: Early anthropogenic $\mathrm{CH}_{4}$ emissions and the variation of $\mathrm{CH}_{4}$ and ${ }^{13} \mathrm{CH}_{4}$ over the last millennium, Global Biogeochem. Cy., 22, GB1002, doi:1010.1029/2007GB002961, 2008.

Jarvis, P. G., Massheder, J. M., Hale, S. E., Moncrieff, J. B., Rayment, M., and Scott, S. L.: Seasonal variation of carbon dioxide, water vapor, and energy exchanges of a boreal black spruce forest, J. Geophys. Res., 102, 28953-28966, 1997.

JCGM: International Vocabulary of Metrology - Basic and General Concepts and Associated Terms 3rd Edition, JCGM 200:2008, online available at: http://www.bipm.org/en/publications/guides/ vim.html, 2008.

Keppler, F., Hamilton, J. T. G., Brass, M., and Rockmann, T.: Methane emissions from terrestrial plants under aerobic conditions, Nature, 439, 187-191, 2006.

Keppler, F., Hamilton, J. T. G., McRoberts, W. C., Vigano, I., Brass, M., and Rockmann, T.: Methoxyl groups of plant pectin as a precursor of atmospheric methane: evidence from deuterium labelling studies, New Phytol., 178, 808-814, 2008.

King, G. M.: Ecological aspects of methane oxidation, a key determinant of global methane dynamics, Advances in Microbial Ecology, 12, 431-468, 1992.

Kirschbaum, M. U. F., Bruhn, D., Etheridge, D. M., Evans, J. R., Farquhar, G. D., Gifford, R. M., Paul, K. I., and Winters, A. J.:
A comment on the quantitative significance of aerobic methane release by plants, Functional Plant Biology, 33, 521-530, 2006.

Kirschbaum, M. U. F. and Walcroft, A.: No detectable aerobic methane efflux from plant material, nor from adsorption/desorption processes, Biogeosciences, 5, 1551-1558, 2008, http://www.biogeosciences.net/5/1551/2008/.

Le Mer, J. and Roger, P.: Production, oxidation, emission and consumption of methane by soils: A review, Eur. J. Soil Biol., 37, 25-50, 2001.

Leuning, R., Denmead, O. T., Miyata, A., and Kim, J.: Source/sink distributions of heat, water vapour, carbon dioxide and methane in a rice canopy estimated using Lagrangian dispersion analysis, Agr. Forest Meteorol. 104, 233-249, 2000.

McKenzie, R., Smale, D., and Kotkamp, M.: Relationship between UVB and erythemally weighted radiation, Photochemical \& Photobiological Sciences, 3, 252-256, 2004.

McLeod, A. R., Fry, S. C., Loake, G. J., Messenger, D. J., Reay, D. S., Smith, K. A., and Yun, B. W.: Ultraviolet radiation drives methane emissions from terrestrial plant pectins, New Phytol., 180, 124-132, 2008.

Megonigal, J. P. and Guenther, A. B.: Methane emissions from upland forest soils and vegetation, Tree Physiol., 28, 491-498, 2008.

Meirink, J. F., Bergamaschi, P., Frankenberg, C., d'Amelio, M. T. S., Dlugokencky, E. J., Gatti, L. V., Houweling, S., Miller, J. B., Rockmann, T., Villani, M. G., and Krol, M. C.: Four-dimensional variational data assimilation for inverse modeling of atmospheric methane emissions: Analysis of SCIAMACHY observations, J. Geophys. Res., 113, D17301, doi:17310.11029/12007JD009740, 2008.

Messenger, D. J., McLeod, A. R., and Fry, S. C.: The role of ultraviolet radiation, photosensitizers, reactive oxygen species and ester groups in mechanisms of methane formation from pectin, Plant Cell Environ., 32, 1-9, 2009.

Miller, J. B., Gatti, L. V., d'Amelio, M. T. S., Crotwell, A. M., Dlugokencky, E. J., Bakwin, P., Artaxo, P., and Tans, P. P.: Airborne measurements indicate large methane emissions from the eastern Amazon basin, Geophys. Res. Lett., 34, L10809, doi:10810.11029/12006GL029213, 2007.

Molotch, N. P., Blanken, P. D., Williams, M. W., Turnipseed, A. A., Monson, R. K., and Margulis, S. A.: Estimating sublimation of intercepted and sub-canopy snow using eddy covariance systems, Hydrol. Process., 21, 1567-1575, 2007.

Monson, R. K., Burns, S. P., Williams, M. W., Delany, A. C., Weintraub, M., and Lipson, D. A.: The contribution of beneath-snow soil respiration to total ecosystem respiration in a high-elevation, subalpine forest, Global Biogeochem. Cy., 20,GB3030, doi:3010.1029/2005GB002684, 2006.

Monson, R. K., Turnipseed, A. A., Sparks, J. P., Harley, P. C., ScottDenton, L. E., Sparks, K., and Huxman, T. E.: Carbon sequestration in a high-elevation, subalpine forest, Glob. Change Biol., 8, 459-478, 2002.

Parrish, D. D., Hahn, C. H., Fahey, D. W., Williams, E. J., Bollinger, M. J., Hubler, G., Buhr, M. P., Murphy, P. C., Trainer, M., Hsie, E. Y., Liu, S. C., and Fehsenfeld, F. C.: Systematic variations in the concentration of $\mathrm{NO}_{\mathrm{x}}\left(\mathrm{NO}\right.$ plus $\mathrm{NO}_{2}$ ) at Niwot Ridge, Colorado, J. Geophys. Res., 95, 1817-1836, 1990.

Parrish, D. D., Trainer, M., Buhr, M. P., Watkins, B. A., and Fehsenfeld, F. C.: Carbon monoxide concentrations and their relation 
to concentrations of total reactive oxidized nitrogen at two rural U.S. sites, J. Geophys. Res., 96, 9309-9320, 1991.

Raupach, M. R.: Anomalies in flux-gradient relationships over forest, Bound. Lay. Meteorol., 16, 467-486, 1979.

Rigby, M., Prinn, R. G., Fraser, P. J., Simmonds, P. G., Langenfelds, R. L., Huang, J., Cunnold, D. M., Steele, L. P., Krummel, P. B., Weiss, R. F., O'Doherty, S., Salameh, P. K., Wang, H. J., Harth, C. M., Muhle, J., and Porter, L. W.: Renewed growth of atmospheric methane, Geophys. Res. Lett., 35, L22805, doi:22810.21029/22008GL036037, 2008.

Roberts, J. M., Hutte, R. S., Fehsenfeld, F. C., Albritton, D. L., and Sievers, R. E.: Measurements of anthropogenic hydrocarbon concentration ratios in the rural troposphere: discrimination between background and urban sources, Atmos. Environ., 19, 1945-1950, 1985.

Rusch, H. and Rennenberg, H.: Black alder (Alnus glutinosa (L.) Gaertn.) trees mediate methane and nitrous oxide emission from the soil to the atmosphere, Plant and Soil, 201, 1-7, 1998.

Sanhueza, E. and Donoso, L.: Methane emission from tropical savanna Trachypogon sp. grasses, Atmos. Chem. Phys., 6, 53155319, 2006, http://www.atmos-chem-phys.net/6/5315/2006/.

Schaeffer, S. M., Anderson, D. E., Burns, S. P., Monson, R. K., Sun, J., and Bowling, D. R.: Canopy structure and atmospheric flows in relation to the $\delta^{13} \mathrm{C}$ of respired $\mathrm{CO}_{2}$ in a subalpine coniferous forest, Agr. Forest Meteorol., 148, 592-605, 2008a.

Schaeffer, S. M., Miller, J. B., Vaughn, B. H., White, J. W. C., and Bowling, D. R.: Long-term field performance of a tunable diode laser absorption spectrometer for analysis of carbon isotopes of $\mathrm{CO}_{2}$ in forest air, Atmos. Chem. Phys., 8, 5263-5277, 2008b, http://www.atmos-chem-phys.net/8/5263/2008/.

Schimel, J. P.: Plant transport and methane production as controls on methane flux from arctic wet meadow tundra, Biogeochemistry, 28, 183-200, 1995.

Schnell, R. C.: Climate Monitoring and Diagnostics Laboratory Summary Report \#27 (2002-2003), online available at: http://www.esrl.noaa.gov/gmd/publications/annrpt27/ contents.html, NOAA, Boulder, CO, 2004.

Scott-Denton, L. E., Rosenstiel, T. N., and Monson, R. K.: Differential controls by climate and substrate over the heterotrophic and rhizospheric components of soil respiration, Glob. Change Biol., 12, 205-216, 2006.

Scott-Denton, L. E., Sparks, K. L., and Monson, R. K.: Spatial and temporal controls of soil respiration rate in a high-elevation, subalpine forest, Soil Biol. Biochem., 35, 525-534, 2003.

Sey, B. K., Manceur, A. M., Whalen, J. K., Gregorich, E. G., and Rochette, P.: Small-scale heterogeneity in carbon dioxide, nitrous oxide and methane production from aggregates of a cultivated sandy-loam soil, Soil Biol. Biochem., 40, 2468-2473, 2008.
Sharpatyi, V. A.: On the mechanism of methane emission by terrestrial plants, Oxidation Communications, 30, 48-50, 2007.

Shipham, M. C., Bartlett, K. B., Crill, P. M., Harriss, R. C., and Blaha, D.: Atmospheric methane measurements in central New England: An analysis of the long-term trend and the seasonal and diurnal cycles, J. Geophys. Res., 103, 10621-10630, 1998a.

Shipham, M. C., Crill, P. M., Bartlett, K. B., Goldstein, A. H., Czepiel, P. M., Harriss, R. C., and Blaha, D.: Methane measurements in central New England: An assessment of regional transport from surrounding sources, J. Geophys. Res., 103, 2198522000, 1998b.

Simpson, I. J., Edwards, G. C., and Thurtell, G. W.: Variations in methane and nitrous oxide mixing ratios at the southern boundary of a Canadian boreal forest, Atmos. Environ., 33, 1141-1150, 1999.

Smith, K. A., Dobbie, K. E., Ball, B. C., Bakken,L. R., Sitaula, B. K., Hansen, S., Brumme, R., Borken, W., Christensen, S., Prieme, A., Fowler, D., Macdonald, J. A., Skiba, U., Klemedtsson, L., Kasimir-Klemedtsson, A., Degorska, A., and Orlanski, P.: Oxidation of atmospheric methane in Northern European soils, comparison with other ecosystems, and uncertainties in the global terrestrial sink, Glob. Change Biol., 6, 791-803, 2000.

Terazawa, K., Ishizuka, S., Sakatac, T., Yamada, K., and Takahashi, M.: Methane emissions from stems of Fraxinus mandshurica var. japonica trees in a floodplain forest, Soil Biol. Biochem., 39, 2689-2692, 2007.

Vigano, I., van Weelden, H., Holzinger, R., Keppler, F., McLeod, A., and Röckmann, T.: Effect of UV radiation and temperature on the emission of methane from plant biomass and structural components, Biogeosciences, 5, 937-947, 2008, http://www.biogeosciences.net/5/937/2008/.

Wang, Z.-P., Gulledge, J., Zheng, J.-Q., Liu, W., Li, L.-H., and Han, X.-G.: Physical injury stimulates aerobic methane emissions from terrestrial plants, Biogeosciences, 6, 615-621, 2009, http://www.biogeosciences.net/6/615/2009/.

Wang, Z. P., Han, X. G., Wang, G. G., Song, Y., and Gulledge, J.: Aerobic methane emission from plants in the Inner Mongolia steppe, Environ. Sci. Technol., 42, 62-68, 2008.

Wickland, K. P., Striegl, R. G., Mast, M. A., and Clow, D. W.: Carbon gas exchange at a southern Rocky Mountain wetland, 19961998, Global Biogeochem. Cy., 15, 321-335, 2001.

Yi, C., Monson, R. K., Zhai, Z., Anderson, D. E., Lamb, B., Allwine, G., Turnipseed, A. A., and Burns, S. P.: Modeling and measuring the nighttime drainage flow in a high elevation subalpine forest ecosystem with complex terrain implications for advective $\mathrm{CO}_{2}$ fluxes, J. Geophys. Res., 110, D22303, doi:22310.21029/22005JD006282, 2005. 